\title{
SAFETY AND TOXICITY COMBINING RADIATION THERAPY WITH A BIOLOGIC THERAPY IN LOCALLY ADVANCED HEAD AND NECK SQUAMOUS CELL CANCER AT THE KLAIPEDA UNIVERSITY HOSPITAL CLINICAL PRACTICE
}

\author{
Jurga Remeikienė, Aista Plieskienė, Alvydas Česas, Jūratė Kasnauskienè \\ Klaipeda University Hospital, Lithuania
}

Key words: cetuximab, radiotherapy, head and neck cancer, toxicity, risk factor, HPV.

\begin{abstract}
Summary
We retrospectively reviewed head and neck cancer cases, treated cetuximab concomitantly with radiotherapy in Klaipeda University Hospital. Comparison of acute side efects of bioradiotherapy and survival analysis.
\end{abstract}

\section{Introduction}

According to the National Cancer Registry data, head and neck cancer prevalence is persistant. Head and neck tumors are still in the sixth place in terms of distribution in the world. Head and neck cancers account for more than 3 $\%$ of all new cancers worldwide [1].

Worldwide public health programms led to the decline of the rates of head and neck cancers (oral cavity, hypopharyngeal, laryngeal cancers) since the 1980's [2]. It was mostly influenced by the decrease of tobacco use. In the same time oropharyngeal cancer rates initially remained constant and then began to rise. In the literature, the data of Toronto study of 6,085 patients showed that the proportion of all head and neck cancers classified as oropharyngeal cancers increased from $23,3 \%$ to $31,2 \%$ within ten years [3].

It is now estimated that $70-90 \%$ of oropharyngeal cancers are caused by HPV. Some literature data suggest that another type of head and neck cancers like nasopharyngeal can be HPV positive[4]. HPV positive tumors are different from HPV negative tumors [4]. HPV related oropharyngeal tumors typically present with small tumors spreading to the lymph nodes (N2/N3). Those tumors are presented like cysts in computer tomography [5]. We know from studies that these infections have a predisposition to induce cervical cancer. HPV virus replicates in the squamous epithelia areas. The virus is a double-stranded DNA viruse. After infection in the cells it uses DNA replication mechanisms to produce HPV oncoproteins, that suppress or eliminate natural tumor suppressors like p53.

Epidemiologic data have strongly linked cigarette smoking and alcohol consumption to the development of certain cancers [6]. Tobacco and alcohol are important etiologic agents in squamous-cell carcinoma of the head and neck. Carcinogens may leave unique "fingerprints" in the form of specific mutations that cause the initiation or progression of cancer [7]. Mutation of the p53 gene, the most common genetic alte ration, has been linked to tobacco smoking in squamous-cell carcinoma of the head and neck. In most of the patients with head and neck tumors, squamous cell carcinomas are diagnosed in stages III and IV. These patients are usually assigned to radiation therapy in combination with chemotherapy or radiation therapy alone. Surgical treatment options are limited, selectively administered to patients as a „saving“ treatment when limited respiratory function, the threat of aspiration [8]. Administration of radiation therapy in combination with chemotherapy improved local disease control and overall survival rates, but increases the toxicity of treatment. The most common side effects are taste disorders, pain, dysphagia, xerostomia, and mucositis.

A meta-analysis confirmed this medication impact improved survival results in combination with radiotherapy $[9,10]$, actively analyzes concomitant treatment determined by comparing the toxicity cisplatin and cetuximab concomitant therapy. Cetuximab induced severe skin reactions, which occur acne type rash, localized in the face, neck and upper chest and the back surface of the skin. Rash intensity directly correlates with increased tumor sensitivity bioradiotherapy, radiation therapy, and prolonged survival without disease recurrence [10].

Purpose of the study - to identify the frequencies of severe and other side effects cased by bioradiotherapy, 


\section{4}

dose exposure of radiotherapy and biological therapy with cetuximab, radiation therapy and cetuximab infusions deferral rate for any reason. To determine whether the tumors were HPV positive.

\section{Patients and methods}

Data of the patients with head and neck tumors treated in Klaipeda University Hospital from 2011-07-08 to 201305-06 concomitantly with cetuxsimab and radiotherapy were analysed.

We included 12 patients with newly diagnosed squamous-cell carcinoma, with locally advanced head and neck malignant tumors, and were not treated for progressive head and neck cancer previously. The majority of patients were men, 11 cases (92\%). The average age was 48 years , the youngest man was 44 years old, the eldest - 63 years of age.

Average duration of concomitant treatment was 7 weeks (from 6.5 to 8 weeks). Cetuximab introductory infusion of $400 \mathrm{mg} / \mathrm{m}^{2}$ was administered to all patients 1 week before concomitant radiobiotherapy and continued $250 \mathrm{mg} /$ $\mathrm{m}^{2}$ weekly mode until the last week of radiotherapy. Standard cetuximab premedication was used, according to the SPC. Patients were administered from 6 to 8 weekly infusions of cetuximab (an average of 7 infusions). Radical radiotherapy doses ranged from 66 to $70 \mathrm{~Gy}(1,8-2 \mathrm{~Gy} / \mathrm{fr})$. Radical radiation therapy was completed for two patients, with the realization of a dose of $40 \mathrm{~Gy}$ and $50.4 \mathrm{~Gy}$, because of treatment mediated toxicity, grade 3 dehydration, grade 3 mucositis and related pathology. One patient had a 5 day radiotherapy break.

A retrospective examination of the histological material of 12 patients was performed by detection of HPV DNA using the polymerase chain reaction.

We assessed the smoking history of the patients.

\section{Results}

Any degree toxicity according to RTOG and CTC EA v.4 [11] of concomitant biological and radiation therapy occurred in all 11 patients (100\%) (one patient deleted from medication-induced toxicity analysis). In terms of the RTOG scale graduation, from 1 to grade 3 mucositis was diagnosed to $8(73 \%)$ patients, $3(27 \%)$ patients had grade 3 mucositis, while grade 4 mucositis was not observed. First and second grade radiation therapy lesion of head and neck skin was detected in 5 patients $(45 \%), 6$ patients $(54 \%)$ had grade 3 lesion. The specific biological therapy lesions were measured by CTCAE v. 4 common toxicity criteria. Only one patient had grade 1 acne type rash. All other patients experienced a more pronounced acne type rash. Six pa- tients experienced grade 2 acne type rash (54\%), and four patients (27\%) experienced grade 3 acne-like skin rash. Grade 3 dehydration, grade 3 mucositis, intense pain in the mouth demanded inpatient (serious adverse event) intravenous substitution of fluids, electrolytes, proteins, carbohydrates and fat emulsions. There were only 3 of such patients $(27 \%)$.

In this analysis the toxicity was evaluated according to two scales, as this method better assess the specific skin damage due to exposure to ionizing radiation and EGFR inhibitor therapy. Mucocutaneous toxicity has been determined by a dermatologist. All patients complained of taste disorders (grade 1-2), difficulty swallowing (grade 1-2), pain in the mouth, throat, but not higher than second grade. Bad breath, mucosal dryness (xerostomia) was observed in all 11 patients, but the toxicities CTCAE v.4 was not higher than grade 2. One patient experienced grade 4 toxicity according to CTCAE v.4. The patient was diagnosed with anaphylactic reactions to cetuximab and required immediate intensive care. Hematological toxicities were extremely rare. Three patients (25\%) experienced (grade 1-2) toxicity. No patient was in need for preventive gastrostomy or feeding tube.

Only three medication cetuximab infusion were postponed, one for grade 3 dehydration, one for grade 3 mucositis and grade 3 acne type rash. Concomitant bioradiotherapy was not realized in one patient due to cetuximab-induced anaphylactic reaction. The patient continued to be treated with radiation therapy.

Throughout the investigated hitological material HPV DNA was not found. Most of the patients had a smoking history of more than 20 years: $9(75 \%)$ were smokers, 3 $(25 \%)$ patients were non-smokers.

Deaths due to any cause were not recorded through patient treatment period. Survival after treatment was from 2 to 3 months for $3(27 \%)$ patients, 1 year for $2(18 \%)$ patients, 2 years for $3(27 \%)$ patients, $4(36 \%)$ patients survived more than 3 years, they have their active monitoring continued. Data was analyzed in June 2016.

\section{Discussion}

Administration of radiation therapy in combination with chemotherapy improves control of locally advanced head and neck malignant tumor and overall survival rates, but increases the toxicity of treatment $[12,13]$. The most common acute reactions are taste disturbance, pain, dysphagia, xerostomia, mucositis, dermatitis, rashes [14]. According to Bonner. et al., the acute toxicity of radiation had not increased after adding cetuximab for concomitant treatment [14], while the analysis of the Irish study results 
(analysis of 67 clinical cases) showed that there were more of severe cases of acute toxicity associated with concomitant bioradiotherapy than in Bonner study (acute actinogenic dermatitis diagnosed in $62 \%$ of cases vs. $18 \%$ in the cisplatin group, mucositis in $74 \%$ vs. $42 \%$ ). Acne type rash did not occur on concomitant chemoradiation therapy with cisplatin, vs $11 \%$ of cases in cetuximab-treated group [12]. These patients have lost more than $10 \%$ of their body weight more rarely. In chemoradiation therapy with cisplatin group specific treatment due to possible toxicity was interrupted twice as often compared to cetuximab group of patients (52 vs. $26 \%$.) $[12,15]$. However, the heterogenecity of the results for the most part could result in patient selection problems. It is observed that mostly asymptomatic, ambulatory patients with good functional were selected in the cetuximab group. There is also a lack of data of the impact of HPV (human papilloma virus) on the results.

After a retrospective analysis of the results of the first patients treated with Klaipeda University Hospital with bioradiotherapy, we looked at the skin changes, typical side effects of cetuximab. They were expressed more often than in published results of randomized clinical trials, and grade 3 dermatitis was seen in every second patient treated with bioradiotherapy. Mucositis were less pronounced in these patients compared with in patients with head-neck malignant tumors and chemoradiation therapy.

HPV was not found in the histological material of our analyzed patients. They are evalued as HPV-negative cancers. The data was potentially negative because of the small sample size of patients, and insufficient quantity of oropharyngeal tumors in the sample. HPV-positive tumors have a better overall survival rates, better response to treatment outcomes, compared with HPV-negative tumors, which are caused by other risk factors such as smoking, alcohol use.

According to J. Hopkins study that compared survival results of HPV-positive and HPV-negative tumor patients, 3 year survival rate was $93 \%$ in the HPV-positive group and only $50 \%$ in HPV-negative group, with relapse observed after 2-4 years after the primary treatment.

Other study data is similar, 3 year survival rate of patients with HPV-negative head and neck tumors was only $57 \%$. Three year survival rate in our patient sample was only $37 \%$.

\section{Conclusion}

Bioradiotherapy is an effective treatment method of locally advanced head and neck malignant tumors, with the toxicity profile different from chemoradiation therapy. During the observation period skin toxicity was more pronounced than mucosal lesions, systemic haematological toxicity did not occur, ordinary appointment of cetuximab was rarely (almost 3 times) delayed. Less severe mucous lesions frequently leads to the hypothesis that late beam reactions may be less pronounced in concomitant treatment, in particular relating to fibrotic changes in soft tissue. Careful selection of patients, the prophylaxis of side effects of biological therapy and qualified multidisciplinary patient care during the bioradiotherapy allows to proceed with the radical treatment of head and neck malignant tumors without interruptions as well as to achieve better local tumor control results.

We await future investigations into mechanism behind such enhanced toxicity, more evidence about HPV - negative and HPV- positive correlation between cancer survival rate, while when there are other risk factors like smoking.

\section{Conflict of interest statement}

There does not exist any conflict of interest.

\section{References}

1. Pulte D, Brenner H. Changes ir survival in head and neck cancers in late 20th and early 21 st century: a period analysis. Oncologist 2010; 15(9): 99-1001.

http://dx.doi.org/10.1634/theoncologist.2009-0289

2. Smith EM, Ritchie JM, Summersgill KF. et al. Human papillomavirus in oral exfoliated cells and risk of head and neck cancer. J Natl Cancer Inst 96:449-455, 2004.

http://dx.doi.org/10.1093/jnci/djh074

3. Habbous S, Chu KP, Qiu X, La Delfa A, Harland LT. et al. The changing incidence of human papillomavirus-associated oropharyngeal cancer using multiple imputation from 2000 to 2010 at a Comprehensive Cancer Centre. 2013 Dec;37(6):8209. doi: 10.1016/j.canep.2013.09.011. Epub 2013 Nov 1. http://dx.doi.org/10.1016/j.canep.2013.09.011

4. Atighechi HYPERLINK http://www.ncbi.nlm.nih.gov/ pubmed/?term=Atighechi\%20S\%5BAuthor\%5D\&cauthor=tru e\&cauthor_uid=25265358" S et al. Human papilloma virus and nasopharyngeal carcinoma: pathology, prognosis, recurrence and mortality of the disease. Exp HYPERLINK http://www. ncbi.nlm.nih.gov/pubmed/25265358" HYPERLINK http:// www.ncbi.nlm.nih.gov/pubmed/25265358"Oncol HYPERLINK http://www.ncbi.nlm.nih.gov/pubmed/25265358". 2014 Sep;36(3):215-6.

5. Haddad R. Human papillomavirus-associated head and neck cancer. In Brockstein B, ed. UpToDate. Waltham, MA: UpToDate; 2013. Accessed December 7, 2013.

6. Carbone D. Smoking and cancer. Am J Med 1992;93:Supp1 1A:13S-17S.

http://dx.doi.org/10.1016/0002-9343(92)90621-H

7. Harris CC, Hollstein M. Clinical implications of the p53 tumorsuppressor gene. N Engl J Med 1993;329:1318-1327. 
http://dx.doi.org/10.1056/NEJM199310283291807

8. Engl J Med 2006 Exhibition; 349: 2091-2098.

9. Levy AR. Indirect comparison of the efficacy of cetuximab and cisplatin in squamous cell carcinoma of the head and neck. Current Medical Research \& Opinion 2011; 27(12): 2253-2259. http://dx.doi.org/10.1185/03007995.2011.633989

10. 10] Bonner JA, Harari PM, Giralt J. et al. Radiotherapy plus cetuximab for locoregionally advanced head and neck cancer: 5-year survival data from a phase 3 randomised trial, and relation between cetuximab-induced rash and survival. Lancet Oncol 2010; 11:21-8. http://dx.doi.org/10.1016/S1470-2045(09)70311-0

11. Common Terminology Criteria for Adverse Events (CTCAE). Version 4.0. Published: May 28, 2009 (v4.03:June14,2010). U.S.Department of Healths and Human services. http:// evs.nci.nih.gov/ftp1/CTCAE/CTCAE_4.03_2010-06-14_ QuickReference_8.5x11.pdf

12. Walsh L, Gilliam C, Dunne M. et al. Toxicity of cetuximab versus cisplatin concurrent with radiotherapy in locally advanced head and neck squamous cell cancer (LAHNSCC). Radiother and Oncolo 2011;98:38-41.

http://dx.doi.org/10.1016/j.radonc.2010.11.009

13. Ang KK, Zhang QE, Rosenthal DI. et al. A randomized phase III (RTOG 0522) of concurrent accelerated radiation plus cisplatin with or without cetuximab for stage III-IV head and neck squamous cell carcinomas. J Clin Oncol 2011;29:abstr 5501 .
14. Bonner JA, Harari PM, Giralt J. et al. Radiotherapy plus cetuximab for squamous-cell carcinoma of the head and neck. N Engl J Med 2006;354:567-78.

http://dx.doi.org/10.1056/NEJMoa053422

15. Bourhis J, Lefebvre JL, Vermorken JB. Cetuximab in the management of locoregionally advanced head and neck cancer: expanding the treatment options? Eur J Cancer. 2010 Jul;46(11):1979-89. doi: 10.1016/j.ejca.2010.05.015. Epub 2010 Jun 17.

http://dx.doi.org/10.1016/j.ejca.2010.05.015

\section{VIETIŠKAI IŠPLITUSIU GALVOS-KAKLO PIKTYBINIU NAVIKU BIOSPINDULINIO GYDYMO ŠALUTINIU POVEIKIŲ ANALIZĖ KLAIPĖDOS UNIVERSITETINĖJE LIGONINĖJE}

\section{J. Remeikienė, A. Plieskienė, A. Česas, J. Kasnauskienė}

Raktažodžiai: cetuksimabas, spindulinė terapija, galvos-kaklo navikai, toksiškumas, rizikos faktoriai, ŽPV.

Santrauka

Retrospektyvi apžvalga galvos- kaklo navikų klinikinių atvejų, gydytų cetuksimabu derinyje su spinduline terapija, Klaipedos universitetinejje ligoninèje. Biospindulinio gydymo šalutinių poveikių, išgyvenamumo palyginamoji analizè.

Adresas susirašinèti: jkanisauskaite@gmail.com

Gauta 2016-11-04 